\title{
Occurrence of Chromosomal Aberrations in Human Populations of Two Endogamous Groups of Haryana
}

\author{
Abhay Singh Yadav ${ }^{1 *}$, Surender Singh ${ }^{2}$, Manoj Kumar Sharma ${ }^{1}$ and Preeti Arora ${ }^{1}$ \\ 1. Human Genetics Laboratory, Department of Zoology, Kurukshetra University, \\ Kurukshetra 136119, Haryana, India \\ 2. Govt. College, Jind, Haryana, India \\ E-mail: abyzkuk@gmail.com
}

KEYWORDS Chromosomal aberration; satellite frequency; mutagens; Meos and Sunni Muslims; Haryana

\begin{abstract}
Cytogenetic assays in peripheral blood lymphocytes (PBL) have been done to assess the incidences of chromosomal aberrations among Meos and Sunni Muslims of Haryana. Baseline frequencies of chromosome aberrations (CA) were assessed in 28 subjects from each cast. The mean frequency of chromosomal gaps in Meos was found to be $0.786 \pm 0.686$ and the frequency of chromosomal break was $0.429 \pm 0.504$. Mean frequency of the satellite association in Meos was found to be $1.357 \pm 1.821$. Among the Sunni Muslims the mean frequency of chromosomal gaps was found to be $1.250 \pm 0.701$ and the frequency of chromosomal breaks was $0.643 \pm 0.488$. Mean frequency of satellite in Sunni Muslims was found to be $1.250 \pm 1.435$. Statistically non-significant differences were observed for the gaps, break and satellite associations, whereas values for total aberrations were found to be statistically significant among Meos and Sunni Muslims. The mean values for chromosomal aberrations and satellite associations were higher in Sunni Muslims (1.893) than in Meos (1.214).
\end{abstract}

\section{INTRODUCTION}

Routine exposure to a variety of mutagens, carcinogens, other chemicals and radiations makes it necessary to analyze the cells at metaphase as these can be a health hazard to the future generations. Peripheral blood lymphocyte culture techniques have been found to be of practical importance in analyzing the detailed morphology of mammalian chromosome. Human chromosomes have been repeatedly studied (Ford et al. 1958; Tjio and Puck 1958 and Chu and Giles 1959). Tissue culture technique also enables us to recognize structural chromosomal aberrations. This method is used to monitor people exposed to various mutagens and carcinogens (Hedner et al. 1982). Exposure to physical or chemical agents, viruses and life style habits including smoking and alcohol consumption affect the genetic material of the individual that can be detected in the form of various types of chromosomal aberrations. Induction of human lymphocytes with physical agents like ionizing radiations, ultra violet rays and chemical agents

Address all correspondence to:

Dr. Abhay Singh Yadav

Professor,

Human Genetics Lab., Department of Zoology,

Kurukshetra University, Kurukshetra 136119 ,

Haryana, India

Telephone: +91-9416173289.

E-mail: abyzkuk@gmail.com may lead to either double stranded breaks (exposed at $G$ phase of the cell) in the DNA that can be equated with the chromosome breaks (Wolff 1973, 1978; Evans 1977), and the mispairing of these breaks leads to the formation of the aberrant chromosome that after replication give rise to full chromosome aberrations involving both chromatids or lesions in the chromosomes that, if unpaired, lead to aberrations of only chromatid type rather than full chromosome aberrations irrespective of the part of the cell cycle in which the cells are exposed. Occurrence of chromosomal aberrations indicates the biological consequences of the exposure as well as signal a potential problem in the population of even seemingly normal cells, where it is exceedingly difficult to quantify any abnormalties. Kucerova et al. (1985) carried out cytogenetic investigation on newborns of three distinct areas of Czechoslovakia to study the effect of different levels of chemical pollution in the environment and observed a significant increase in the chromosomal aberrations. Bender et al. (1988) observed more frequency of chromatid deletions and dicentric chromosomes in healthy individuals but no significant influence of smoking, age and sex on these aberrations. Similarly no correlation was found between dicentric and tricentric chromosomes, acentric fragments, double minutes and age, sex and radiation exposure (Awa and Neel, 1986). However, other studies showed the influ- 
ence of age, sex, race and cigarette smoking on the frequency of chromosomal aberrations (Obe and Herha 1978; Evans 1979; Lambert et al. 1978; Krishna Murthy 1979; Hopkin and Evans 1980; Butler 1981; Vijaya laxmi and Evans 1982; Soper et al. 1984; Margolin and Shelby 1985; Galloway et al. 1986; Wulf et al. 1986; Yadav and Thakur 2000 a, b; Yadav et al. 2001a).

People engaged in different occupations like farming and in industries are exposed to a variety of chemicals which are mutagens and/or carcinogens. Cytogenetic monitoring of such personnel includes study of numerical and structural chromosome aberrations. Most of the chemicals used by the agricultural workers and pesticide sprayers have produced chromosomal aberrations in human somatic cell (Czeizel et al. 1973; Pilinskaya 1974, 1982a, b, Van Bao et al. 1974; Larripa et al. 1983; Kurinniz 1984; Paldy et al. 1987; Rita et al. 1987; Sharma and Sobti 1988; Rupa et al. 1989; Yadav and Kaushik 2002). An increase in chromosomal aberrations has also been observed in the cytogenetic investigations of the hospital workers dealing with anesthesia and antitumour drugs (Waksvik et al. 1981; Laurent et al. 1984; Sort et al. 1984; Benhamou et al. 1988). Increase in chromosomal aberration has also been observed in the cytogenetic investigations of Goldsmiths (Yadav and Seth 1998a), nickel-chrome electroplaters (Yadav et al. 2001c) and Stainless steel welders (Yadav et al. 2001b). There is only one published report of cytogenetic investigations on a random sample of general population from Haryana (Yadav et al. 2002).

Before evaluating the biological significance of induced aberrations it is necessary to know the frequency and variability in the frequency of aberrations in normal population which is of great interest in itself and for comparative purposes. Accordingly, during the present investigation on the Meos and Sunni Muslims of Haryana, the base line frequency of chromosome aberrations has been evaluated.

\section{MATERIALSAND METHODS}

Peripheral blood cultures of normal individuals belonging to Meos and Sunni Muslims were set up to study the presence of chromosomal aberrations. For cytogenetic studies 28 individuals from each caste were selected randomly from the Meo and Sunni Muslim population from Gurgaon, Faridabad, Kaithal,
Jind and Kurukshetra districts of Haryana. About $10 \mathrm{ml}$ blood was taken from each individual in heparin coated green top tube by veinpuncture in the arm. Short term lymphocyte cultures were setup (Moorhead et al. 1960).

For study of chromosomal aberrations, the cells were cultured for 48 hours, slides were prepared and stained with $4 \%$ Giemsa solution. At least 100 cells (first division metaphases) from each subject were scored. The criteria of ISCN (1985) were used for categorizing the chromosome aberrations. Only gaps and breaks were taken into account. Statistical analysis was done by applying student's 't' test (Colton 1980).

\section{Satellite Associations}

For study of satellite associations, cells were harvested at $72 \mathrm{~h}$. In each sample 100 metaphases were analyzed. The SAs involve a specific arrangement of acrocentric chromosomes (D.G.) with their satellites directed towards each other. The types of SAs recorded during the present study were as follows:
(1) D-D
(5) $2 \mathrm{G}-\mathrm{D}$
(2) D-G
(6) $2 \mathrm{G}-2 \mathrm{D}$
(3) G-G
(7) $3 \mathrm{D}$
(4) 2D-G

The following criteria of SAs used by Hansson (1970) were applied.

1. The satellite ends of the associating chromosomes had to be directed towards each other with their longitudinal axes meeting between their short arm.

2. The distance between the centromeres of associated chromosomes should not exceed the total length of one ' $G$ ' chromosome after excluding its satellite. If a thread is visible between the short arms of two satellite chromosomes, the distance could be somewhat longer, but should always be less than the total length of one chromosome, the satellite excluded.

\section{RESULTS}

The results regarding chromosomal aberrations among the two endogamous groups were evaluated. The occurrence of chromosomal aberrations (gaps and breaks) and satellite associations in different individuals are given in the tables 1, 2 .

The mean frequency of chromosomal gaps in 
Table 1: Results of the chromosome aberrations among Meos.

\begin{tabular}{|c|c|c|c|c|c|}
\hline $\begin{array}{l}\text { S. } \\
\text { No. }\end{array}$ & Gaps & Breaks & Total & \%age & $\begin{array}{l}\text { Satellite } \\
\text { frequency }\end{array}$ \\
\hline 1. & 1 & - & 1 & 1 & 2 \\
\hline 2. & - & - & - & - & - \\
\hline 3 . & 1 & 1 & 2 & 2 & - \\
\hline 4. & 1 & 1 & 2 & 2 & 1 \\
\hline 5. & - & 1 & 1 & 1 & 2 \\
\hline 6. & 1 & 1 & 2 & 2 & - \\
\hline 7. & - & - & - & - & 3 \\
\hline 8. & 1 & 1 & 2 & 2 & 1 \\
\hline 9. & 2 & - & 2 & 2 & - \\
\hline 10. & - & - & - & - & 2 \\
\hline 11. & 1 & 1 & 2 & 2 & 1 \\
\hline 12. & - & 1 & 1 & 1 & 5 \\
\hline 13. & 2 & 1 & 3 & 3 & - \\
\hline 14. & - & - & - & - & - \\
\hline 15. & 1 & 1 & 2 & 2 & - \\
\hline 16. & 2 & - & 2 & 2 & 2 \\
\hline 17. & 1 & - & 1 & 1 & - \\
\hline 18. & 1 & - & 1 & 1 & 2 \\
\hline 19. & 2 & - & 2 & 2 & 1 \\
\hline 20. & - & 1 & 1 & 1 & - \\
\hline 21 . & 1 & - & 1 & 1 & - \\
\hline 22. & - & - & - & - & 5 \\
\hline 23 . & 1 & - & 1 & 1 & - \\
\hline 24. & 1 & 1 & 2 & 2 & 1 \\
\hline 25. & 1 & - & 1 & 1 & 7 \\
\hline 26. & - & - & - & - & - \\
\hline 27. & - & 1 & 1 & 1 & 3 \\
\hline 28. & 1 & - & 1 & 1 & - \\
\hline
\end{tabular}

Table 2: Results of chromosome aberrations among Sunni Muslims.

\begin{tabular}{|c|c|c|c|c|c|}
\hline $\begin{array}{l}S . \\
\text { No. }\end{array}$ & Gaps & Breaks & Total & \%age & $\begin{array}{c}\text { Satellite } \\
\text { frequency }\end{array}$ \\
\hline 1. & - & 1 & 1 & 1 & - \\
\hline 2. & - & - & - & - & 1 \\
\hline 3. & 1 & 1 & 2 & 2 & - \\
\hline 4. & 2 & 1 & 3 & 3 & - \\
\hline 5. & 1 & - & 1 & 1 & 3 \\
\hline 6. & 1 & 1 & 2 & 2 & - \\
\hline 7. & 2 & - & 2 & 2 & 4 \\
\hline 8. & 2 & 1 & 3 & 3 & - \\
\hline 9. & 1 & 1 & 2 & 2 & - \\
\hline 10. & 1 & - & 1 & 1 & - \\
\hline 11. & - & 1 & 1 & 1 & 3 \\
\hline 12. & 2 & - & 2 & 2 & - \\
\hline 13. & 2 & - & 2 & 2 & 1 \\
\hline 14. & 1 & - & 1 & 1 & - \\
\hline 15. & - & 1 & 1 & 1 & - \\
\hline 16. & 2 & 1 & 3 & 3 & 1 \\
\hline 17. & 1 & 1 & 2 & 2 & 3 \\
\hline 18. & 2 & 1 & 3 & 3 & 1 \\
\hline 19. & 1 & 1 & 2 & 2 & 3 \\
\hline 20. & 1 & - & 1 & 1 & 4 \\
\hline 21. & 2 & - & 2 & 2 & - \\
\hline 22. & 2 & 1 & 3 & 3 & 1 \\
\hline 23. & 1 & 1 & 2 & 2 & - \\
\hline 24. & 2 & 1 & 3 & 3 & 1 \\
\hline 25. & 1 & 1 & 2 & 2 & 2 \\
\hline 26. & 1 & 1 & 2 & 2 & 4 \\
\hline 27. & 1 & 1 & 2 & 2 & 1 \\
\hline 28. & 2 & - & 2 & 2 & 2 \\
\hline
\end{tabular}

Meos was found to be $0.786 \pm 0.686$ and the frequency of chromosomal breaks was $0.429 \pm 0.504$. The mean frequency of total aberration was observed to be $1.214 \pm 0.833$. Mean frequency of the satellite association in Meos was found to be $1.357 \pm 1.821$ (Table 3).

Among the Sunni Muslims the mean frequency of chromosomal gaps was found to be $1.250 \pm$ 0.701 and the frequency of chromosomal breaks was $0.643 \pm 0.488$. The Mean frequency of total aberrations was observed to be $1.893 \pm 0.786$. Mean frequency of satellite in Sunni Muslims was found to be $1.250 \pm 1.435$ (Table 3 ). The t-test values for gaps, breaks and satellite associations were found to be non-significant, while for total aberrations the value were significant in Meos and Sunni Muslims (Table 4).

\section{DISCUSSION}

Analysis of structural chromosome aberrations has proved to be a sensitive method for revealing DNA damage and for detecting exposure to certain genotoxic agents in vivo (Hollstein et al. 1979). The first such abnormality involving centric fusion of a small and large acrocentric autosome was reported (Turpin et al. 1959), while a translocation involving an autosome 3 and a medium sized chromosome was observed in an apparently normal female (Book et al. 1961).

Lubs and Samuelson (1967) observed a considerable variability in breakage frequency $(1 \%$ to $20 \%$ ) in normal subjects with an average 0.051 breaks per cell in culture from five men and 0.083 breaks per cell in culture from five women. Similarly a frequency of $7.8 \%$ of breakage was confirmed in 22 normal subjects by Amarose and Schuster (1971). Other workers have also reported an average breakage frequency exceeding 5\% in the lymphocytes from controls (Brogger 1971). Littlefield and Goh (1973) found a range of $4 \%$ to $7 \%$ breaks in the lymphocyte preparation from both men and women.

Variations in metabolic processes and differences in genetic factors could be responsible for differences in frequencies of breaks (Gripenberg 1965). This view was supported with regard to spontaneous breakages in that the series of cultures from the same person were found to have higher breakage than series of cultures from other individuals. It may also be suggested that undefined seasonal variable may have pronounced 
Table 3: Results of chromosome aberrations and satellite frequency among Meos and Sunni Muslims of Haryana.

\begin{tabular}{llllrr}
\hline Caste & Chromosomal aberration & Mean & S.D. & S.E. & C.V. \\
\hline Meo & Gaps & 0.786 & 0.686 & 0.130 & 84.277 \\
& Breaks & 0.429 & 0.504 & 0.095 & 117.483 \\
& Total & 1.214 & 0.833 & 0.157 & 68.616 \\
Sunni Muslim & Satellite Association & 1.357 & 1.821 & 0.344 & 134.193 \\
& Gaps & 1.250 & 0.701 & 0.132 & 56.080 \\
& Breaks & 0.643 & 0.488 & 0.092 & 75.894 \\
& Total & 1.893 & 0.786 & 0.149 & 41.521 \\
& Satellite Association & 1.250 & 1.435 & 0.271 & 114.800 \\
\hline
\end{tabular}

Table 4: Result of 't-test' for Chromosomal Aberrations among Meos and Sunni Muslims.

\begin{tabular}{|c|c|c|c|c|c|}
\hline \multicolumn{2}{|l|}{ Population } & \multirow{2}{*}{$\begin{array}{l}\text { Gaps } \\
0.6935\end{array}$} & \multirow{2}{*}{$\begin{array}{c}\begin{array}{c}\text { Breaks } \\
\text { frequency }\end{array} \\
1.6142\end{array}$} & \multirow{2}{*}{$\begin{array}{c}\text { Total } \\
\text { aberrations }\end{array}$} & \multirow{2}{*}{$\begin{array}{l}\text { Satellite } \\
0.2442\end{array}$} \\
\hline Meo vs. & Sunni Muslim & & & & \\
\hline & Jat & 0.0478 & 0.3038 & 0.2256 & 0.9596 \\
\hline & Yadav & 0.2380 & 0.3209 & 0.3763 & 0.4260 \\
\hline & Saini & 0.0690 & 0.6815 & 1.0764 & 0.96816 \\
\hline & Kamboj & $2.7535 *$ & 0.9921 & 3.1212 & 0.0788 \\
\hline & Ror & 0.8651 & 1.7042 & 0.1698 & 0.5190 \\
\hline \multirow[t]{5}{*}{ Sunni Muslims vs. } & Jat & $2.6934 *$ & 1.2595 & $2.8413 *$ & 1.2136 \\
\hline & Ahir & $2.3499 *$ & 1.3325 & $2.8903 *$ & 0.7129 \\
\hline & Saini & 1.8328 & 0.0652 & $2.1992 *$ & 1.2698 \\
\hline & Kamboj & 0.2364 & 0.6629 & 0.0528 & 0.1988 \\
\hline & Ror & 1.7634 & 0.0642 & 1.4179 & 1.3759 \\
\hline
\end{tabular}

*Significant $(\mathrm{p}<0.05)$

effect on breakage frequency (Littlefield and Goh 1973). Other factors like sex, age smoking and other environmental pollutants have been reported to increase chromosomal aberration frequencies. Structural chromosome aberrations have been found to be significantly higher in females than in males (Hedner et. al. 1982). Supernumerary acentric fragments were found to be 2.5 times more in females than in males (Bender et al. 1988). However, no such differences were observed between males and females by Gundy and Verga (1983). Significant influence of age on dicentric chromosome was observed (Obe and Herha 1978; Galloway et al. 1986), but no significant influence was observed by Bender et al. (1988). Anderson et al. (1988) found no influence of smoking on chromosome aberrations. However, some reports confirm significant effect of smoking on chromosome aberrations (Obe and Herha 1978; Lambert et al. 1978; Vijaylaxmi and Evans 1982: Yadav and Thakur 2000b, c; Yadav et al. 2001b,c). People engaged in different occupations like farming and workers in industries are exposed to variety of chemicals. Most of chemicals used by industry workers and pesticide sprayers have produced chromosomal aberrations in human somatic cells (Van Bao et al. 1974; Rita et al. 1987;
Sharma and Sobti 1988; Rupa et al. 1989; Yadav and Kaushik 1996a; Yadav and Seth 1998a, b; 2000; Yadav et al. 2001a, b, c).

Satellite Associations: Tjio and Levan (1956) first reported satellites on human chromosomes. All D and G group chromosomes except Y chromosome can have satellites. The satellite chromosomes tend to associate with each other with their satellites directed towards each other and this phenomenon is known as satellite association (SA) of chromosomes. These associations were first of all observed in the human metaphase chromosomes (Ferguson-Smith et al. 1962). These chromosomes are associated together due to the sticky nucleolar material. These associations are involved in nucleolar formation (Hsu 1965). Satellite association tends to lead to translocation and non-disjunction and thus lead to the induction of $\mathrm{D}$ and $\mathrm{G}$ trisomics.

In the present study mean values for chromosomal aberrations and satellite associations were higher in Sunni Muslims (1.893) than Meos (1.214). From the t-test values for gaps, breaks and satellite associations, statistically non-significant differences were obtained whereas values for total aberrations were found to be statistically significant among Meos and Sunni Mus- 
lims (Table 4). The present mean values for chromosomal aberrations and satellite associations obtained in Meos and Sunni Muslims were also compared with those of other populations of Haryana. i.e. Jat, Yadav, Saini, Kamboj and Ror. Non-significant differences were obtained for breaks and satellite associations among these populations. However, significant differences were noted for gaps among Meos and Kamboj, Sunni Muslims and Jat, Sunni Muslims and Ahir. For total aberrations significant differences were observed among Meos and Sunni Muslims, Sunni Muslim and Jat, Sunni Muslim and Ahir, Sunni Muslim and Saini (Table 4).

\section{ACKNOWLEDGEMENT}

The authors are sincerely grateful to the authorities of Kurukshetra University, Kurukshetra for providing laboratory facilities and to CSIR (New Delhi) for providing financial assistance to S. Singh.

\section{REFERENCES}

Amarose AP, Schuster CR 1971. Chromosomal analyses of bone marrow and peripheral blood in subjects with a history of illicit drugs use. Arch Gen Psychiat, 25: $181-186$.

Anderson D, Jenkinson PC, Deddney RS 1988. Chromosome aberration, mitogen-induced blastogenesis and proliferative rate index in peripheral lymphocyte from 106 control individuals of the U.K. population. Mutation. Res, 204:407420.

Awa AA, Neel JV 1986. Cytogenetic "rogue" cells: What is their frequency, origin, and evolutionary significance? Proc. Natl. Acad. Sci, (USA), 83c: 1021-1025.

Bender MA, Preston RJ, Leonard RC, Pyatt BE, Gooch PC, Shelby MD 1988. Chromosomal aberrations and sister-chromatid exchange frequencies in peripheral blood lymphocytes of a large human population sample. Mutation Res, 204: 421-433.

Benhamou S, Deprum PP, Garnier HS, Chouroulinkov I 1988. SCEs and chromosome aberrations in lymphocytes of nurses handling cytostatic agents. J Cancer, 41: 350-353.

Book JA, Santesson B, Zetterqvist P 1961. Translocation heterozygosity in man. Lancet, 1: 167.

Brogger A 1971. Apparently spontaneous chromosome damage in human leukocytes and the nature of chromatid gaps. Hum Genet, 13: 1.

Butler MG 1981. Sister Chromatid exchange in 4 human races. Mutation Res, 91: 377-379.

Chu EHY, Giles NH 1959. Human chromosome complements in normal somatic cells in culture. Am J Hum Genet, 11: 63-78.

Colten T 1980. Statistics in Medicine. Boston: Little Brown and Co.
Czeizel E, Van Bao T, Szabo L, Ruzicka P 1973. Human chromosome aberrations on acute organic phosphorus acid ester (pesticide) intoxication ( $\mathrm{Ab}$ stract). Mutation Res, 21: 187-188.

Evans HJ 1977. Molecular mechanism in the induction of chromosome aberrations. In: D. Scott, BA Bridges, FH Sobels (Eds.): Progress in Genetic Toxicology, Amsterdam: Elsevier/North-Holland, pp. 5774.

Evans HJ 1979. The induction of aberrations in human chromosomes following exposure to mutagens/ carcinogen In: P Emmelot, E Kriek (Eds.): Environmental Carcinogens. Amsterdam: Elsevier/ North-Holland, pp. 57-74.

Ferguson-Smith MA, Ferguson-Smith ME, Ellis PM, Dickson M 1962. The site and relative frequencies of secondary constrictions in human somatic chromosomes. Cytogenetics, I: 325-343.

Ford CE, Jacobs PA, Lajtha IG 1958. Human somatic chromosomes. Nature, 181: 1565-1568.

Galloway SM, Berry PK, Nichols WW, Wolman SR, Soper KA, Stolley PD, Archer P 1986. Chromosome aberrations in individuals occupationally exposed to ethylene oxide, and in a large control population. Mutation Res, 170: 55-74.

Gripenberg U 1965. Chromosome studies in some virus infections. Hereditas, 54: 1-18.

Gundy S, Varga LP 1983. Chromosomal aberrations in healthy persons. Mutation Res, 120: 187-191.

Hansson A 1970. Difference in the satellite associations pattern in human population. Hereditas, 66: 21-30.

Hedner K, Hogstedt B, Kolnig AM, Mark-Vendel E, Strombeck B, Mitelman F 1982. Sister chromatid exchange and structural chromosome aberrations in relation to age and sex. Hum Genet, 62: 305309.

Hollstein M, McCann J, Angelosanto FA, Nichols WW 1979. Short term test for carcinogens and mutagens. Mutation Res, 65: 133-226.

Hopkin JM, Evans HJ 1980. Cigarette smoke-induced DNA damage and lung cancer risks. Nature, 283: 388-390.

Hsu TC 1979. Human and Mammalian Cytogenetics. An Historical Perspective New York: Springer Verlag, Pp. 1-181.

ISCN 1985. An International System for Human Cytogenetic Nomenclature. DG Harnden, HP Klinger (Eds.). Published in collaboration with Cytogenet Cell Genet, Karger, Basel.

Krishna-Murthy PB 1979. Frequency of sister chromatid exchanges in cigarette smokers. Hum Genet, 52: 343-345.

Kucerova M, Polivkova Z, Gregor V 1985. Effect of environmental factors on induced chromosomal aberrations in newborns. Mutation Res, 143: 271274.

Kurinniz AJ 1984. Estimation of Pesticides as Mutagens. XIV Annual Meeting of the

European Environmental Mutagen. Society Book Abstracts, 11-14 Sept., Moscow, p. 273.

Lambert B, Lindblad A, Nordenskjold M, Werelius B 1978. Increased frequency of sister-chromatid exchanges in cigarette smokers. Hereditas, 88: 147149 .

Larripa L, Mutos E, Divenueza ML, Brieux de salum S 1983. Sister chromatid exchanges in a human pop- 
ulation accidentally exposed to an organo-phosphorous pesticide. Rev Bras Genet, 6: 719-727.

Laurent C, Frederic J, Leonard AY 1984. SCE frequency in workers exposed to high levels of ethylene oxide in a hospital sterilization service. Int Arch Occp Eniron Health, 54(1): 33-44.

Littlefield LG, Goh KO 1973. Cytogenetic studies in control men and women. Cytogenet Cell Genet, 12: $17-34$

Lubs HA, Samuelson J 1967. Chromosome abnormalities in lymphocytes from normal human subjects. A study of 3720 cells. Cytogenetics, 6: 402-411.

Margolin BH, Shelby MD 1985. Sister chromatid exchanges: A re-examination of the evidence for sex and race differences in humans. Environ Mutagen, 7, Suppl. 4: 63-72

Moorhead PS, Nowell PC, Mellman WJ, Battips DM Hungerford DA 1960. chromosome preparation of leukocytes cultured from human peripheral blood. Exp Cell Res, 20: 613-616.

Obe G, Herha J 1978. Chromosomal aberrations in heavy smokers. Hum Genet, 41: 259-263.

Paldy A, Puskas N, Vinize K, Hadhazi M 1987. Cytogenetic studies on rural population exposed to pesticides. Mutation Res, 187: 127-132.

Pilinskaya MA 1974. Results of cytogenetic examination of people having professional contact with the fundicide Zineb. Genetika, 10: 140-146 (in Russian).

Pilinskaya MA 1982a. Importance of cytogenetic investigations of professional contacts for hygienic evaluation of pesticides, Gig-truda-i-profzabol, 4: 28-32 (in Russian).

Pilinskaya MA 1982b. To the question of the cytogenetic effects of pesticide Pirimor in human peripheral lymphocyte culture in vivo and in vitro. Genetika, 2: 38-72.

Rita S, Reddy PP, Reddy SV 1987. Monitoring of workers occupationally exposed to pesticides in grape garden workers of Andhra Pradesh. Env Res, 44: 1-5.

Rupa DS, Reddy PP, Reddi OS 1989. Frequency of chromosomal aberrations in smokers exposed to pesticides in cotton fields. Mutation Res, 222: 37-41.

Sharma GP, Sobti RC 1988. Mutagenecity of certain agricultural chemicals on in vitro and in vivo system. Nucleus, 31: 120-142.

Soper KA, Stolley PD, Galloway SM, Smith JG, Nichols WW, Wolman SR 1984. Sister chromatid exchange (SCE) report on control subjects in a study of occupationally exposed workers. Mutation Res, 129: 77-88.

Tjio JH, Levan A 1956. The chromosome number of man. Hereditas, 42:1-6.

Tjio JH, Puck TT 1958. The somatic chromosome of man. Proc Nat Acad Sci, 44: 1229-1237.
Turpin R, Lejeune J, Lafourcade J, Gauter M 1959. Aberrations chromosomiques et maladies humanes. La polydysspondylie a 45 chromosomes. C R Acad Sci Paris, 248: 3636.

Van Bao T, Szabo I, Ruzicska P, Czeizel 1974. Chromosome aberrations in patients suffering acute organic phosphate insecticide intoxication. Humangenetik, 24: 33-57.

Vijayalaxmi, Evans HJ 1982. In vivo and in vitro effect of cigarette smoke on chromosomal damage and sister-chromatid exchange in human peripheral blood lymphocytes. Mutation Res, 92: 321-332.

Waksvik H, Kleep O, Brogger A 1981. Chromosome analysis of nurses handling cytostatic agents. Cancer Treat Rep, 65: 607-610.

Wolff S 1973. Chromsome aberrations: mechanisms of cell death. In: JF Duplan, A Chapiro (Eds.): Advances in Radiation Research. 1: 457-465, New York: Godron \& Breach.

Wolff S 1978. Relation between DNA repair, chromosome aberrations and sister chromatid exchanges. In: PC Hanwawalt, EC Friedberg, CF Fox. (Eds.): DNA Repair Mechanism. New York: Academic Press, Pp. 751-760

Wulf HC, Kousgarrd N, Nieburh E 1986. Sister chromatid exchange in childhood in relation to age and sex. Mutation Res, 174: 309-312.

Yadav JS, Kaushik VK 1996. Effect of sulphurdioxide on human chromosomes. Mutation Res, 359: 25-29.

Yadav JS, Kaushik VK 2002. Studies on the genotoxicity of an organophosphorous pesticide Baytex - 1000 . Int J Hum Genet, 2(2): 19-25.

Yadav JS, Kler RS, Chadha P, Yadav AS 2002. Spontaneous chromosomal aberrations in human populations of five endogamous groups of Haryana. J Cytol Genet, 3(NS): $121-126$

Yadav JS, Seth N 1998a. Effect of NO on the somatic chromosome of gold smiths. Environmental Health Perspectives, 106: 643-647.

Yadav JS, Seth N 1998b. Effect of polycyclic aromatic hydrocarbons on somatic chromosomes of coaltar workers. Cytobios, 93: 165-173.

Yadav JS, Thakur S 2000a. Cytogenetic damage in Bidi smokers. Nicotine and Tobacco Res, 2: 97-103.

Yadav JS, Thakur S 2000b. Genetic risk assessment in Hookah smokers. Cytobios, 101: 101-113.

Yadav JS, Thakur S, Chillar AK 2001a. Genetic risk assessment in cigarette smokers. In: Human Ecology in the New Millennium. J Hum Ecol Special Volume, 10: $165-170$

Yadav JS, Yadav AS, Sharma T 2001b. Chromosome damage in lymphocytes of stainless steel welder. Int J Hum Genet, 1 (3): 185-189.

Yadav JS, Yadav AS, Sharma T 2001c. Chromosome damage in nickel-chrome electroplaters. J Hum Ecol, 12(3): 185 - 189 . 